Article

\title{
Open Science and Its Enemies: Challenges for a Sustainable Science-Society Social Contract
}

\author{
Venni V. Krishna \\ School of Humanities and Languages, University of New South Wales, Sydney, NSW 2052, Australia; \\ v.krishna@unsw.edu.au
}

Received: 23 June 2020; Accepted: 22 July 2020; Published: 3 August 2020

\begin{abstract}
Science as a social institution has evolved as the most powerful, highly influential, and sought out institution after the conflicts between science and religion following Galileo. Knowledge as a public good, scientific peer review of science, the prominence of open publications, and the emphasis on professional recognition and scientific autonomy have been the hallmark of science in the past three centuries. According to this scientific spirit, the scientific social system and society formed a unique social contract. This social contract drew considerable institutional and state legitimacy for the openness and public good of science in the service of state and society, all through the post-war period. Openness and public good of science are recognized and legitimized by the scientific community and science agencies at the global level. This paradigm of open science, in varying forms and manifestations, contributed to the progress of systematic knowledge at the service of humankind over the last three centuries. Entering the third decade of the 21st century, the social contract between science and society is undergoing major changes. In fact, the whole paradigm of open science and its social contract is being challenged by various "enemies" or adversaries such as (a) market-based privatized commercial science, (b) industry 4.0 advanced technologies, and (c) a "new iron curtain" on the free flow of science data and information. What is at stake? Are there major changes? Is the very social institution of science transforming? What impact will this have on our contemporary and future sustainable society? These are some important issues that will be addressed in this article.
\end{abstract}

Keywords: ethos of science; science and society social contract; open science; industry 4.0; platform capitalism in science

\section{Introduction}

The conflict between science and society after Galileo in the 17th century finally led to the social legitimacy of science. Science, scientists, and society have waged an unrelenting struggle against religion and other social forces in different periods. In doing so, they allocated a relatively independent space for science to promote a systematic understanding of nature and natural phenomena, thereby benefiting the entire society. These struggles paved the way for solid foundations of scientific method and at the same time generated voluntary support and legitimation from the society towards systematic knowledge. The historical period of renaissance and the scientific revolution, perhaps the most significant period of discovery, demonstrated methods of science for the growth of scientific knowledge in the modern era (see ref. [1,2]). In no uncertain terms, this was indeed an open science, accessible not only to fellow scientists and peers but in various forms for the benefit of society at large. Open science should not be confused with the publication of available scientific information and knowledge on non-refereed online sources, which have proliferated in the last decade. The connotation of open science is similar to good science, and the recent report of The Royal Society, London (2012) clearly explains the merits of open science in its Science as an Open Enterprise [3]. As the Royal Society [3] (p. 8) observes, "not only is open science often effective in stimulating scientific discovery, it may also help to 
deter, detect and stamp out bad science. Openness facilitates a systemic integrity that is conducive to early identification of error, malpractice and fraud, and therefore deters them. But this kind of transparency only works when openness meets standards of intelligibility and assessability-where there is intelligent openness."

Since the 17th century, the scientific social system has developed into one of the most powerful, influential, and popular institutions. Knowledge as a public good, scientific peer review, the prominence of publications, and the emphasis on professional recognition and scientific autonomy according to scientific priorities, remained the hallmarks of science in the past three centuries. American sociologist, Robert Merton's classic thesis on Science, Technology and Society in Seventeenth Century England [4], led to what has come to be known as the most important "paradigm" of autonomous and open academic science encapsulated in his "ethos of science" or "normative structure of science" [5]. Science as a social institution is based on the ethos of universalism, communalism, disinterestedness, and organized skepticism, which remains the cornerstone of open science and is tacitly practiced by the world scientific community in its varying forms. Universalism embodies the objective characteristics of science because acceptance or rejection does not depend on social or personal attributes. The spirit of communalism is opposed to secrets and property rights. Selflessness makes people notice the enthusiasm for knowledge, the lazy curiosity, the altruistic concern that is beneficial to mankind and society as a whole. Organized skepticism means the concept of doubt or scientific temper because it is seen as a methodology and an institutional task. Researchers need to suspend their judgments until the facts are before their eyes. They need to evaluate their beliefs in science based on new empirical evidence. These scientific norms are still the foundation of the relationship between science and society [5]. As Merton defines and explains:

The ethos of science is that affectively toned complex of values and norms which is held to be binding on the man of science. The norms are expressed in the form of prescriptions, proscriptions, preferences and permissions. They are legitimized in terms of institutional values. These imperatives, transmitted by precept and example and reinforced by sanctions are in varying degrees internalized by the scientist, thus fashioning his scientific conscience or, if one prefers a latter-day phrase, his superego. Although the ethos of science has not been codified, it can be inferred from the moral consensus of scientists ... in countless writings toward contraventions of the ethos [5] (pp. 66-67).

This social contract drew considerable intellectual, institutional, and state legitimacy for the openness and public good of science in the service of state and society all through the 20th century. The Humboldt Model of organizing universities, after the establishment of Berlin University, gained prominence in Germany and other European countries. When Britain established the Department of Scientific and Industrial Research (DSIR) around 1918, it assigned tremendous autonomy to the council in peacetime. One is referring to the Haldane Principle. Haldane served as the chairman of the committee that recommended this policy between 1909 and 1918 (see ref. [6]). Similar was the case of other scientific research councils in Canada, Australia, India, and South Africa during the 1950s. Academic or basic research gained tremendous policy support in this period. In the USA, the Science: The Endless Frontier (1945) report [7], provided an important linear model of innovation for the growth of an autonomous science and society relationship. The era of the linear model of innovation gave a big boost to basic and fundamental research. The very establishment of the National Science Foundation and its fourfold increase in research funding during the 1950s and 1960s is not unrelated to the Science: The Endless Frontier report [7]. Michael Polanyi advocated the freedom and autonomy of scientific institutions in his key and influential paper The Republic of Science (1962) [8]. In Britain, the Haldane Principle provided tremendous legitimacy to autonomous science organizations of research councils. In many ways, the foundation for a science-driven or linear innovation model was laid by these post-war events and the movement towards open and autonomous science. Even leading economists such as Mansfield (1991) [9] argued for basic research and the way in which it contributed to industry and society. Various technocratic and intellectual voices upheld the importance of autonomous science 
and its organization, which in many ways defined the tacit, informal but very powerful science-society relationship or social contract. The contract gained legitimacy in the organization of public and private research laboratories, science councils, and academies. Actors in these institutions produced systematic knowledge and advanced the state of scientific knowledge yielding social benefits. It is for this reason that the state and government funded scientific research out of public interest but usually did not interfere with research autonomy. Scientific knowledge is managed by a peer system [10] (p. 138).

Open science has evolved as a movement that promotes scientific research data and advances systematic knowledge which is accessible by a wider society at all levels subject to certain peer-based institutional measures. There is a wide international recognition that open science is composed of some critical elements such as open data, open material, open source, open access, open peer review, and open educational resources in the interest of maintaining a healthy science-society relationship and its social contract. UNESCO's intervention in making public the Human Genome Project data is a particularly good example. For instance, the European Commission, since 2016, has prioritized open science along with open innovation to the world in its path to research, science, and innovation policy that aligns with an open digital and global environment. In addition, a recent report on Science as an Open Enterprise by the Royal Society of London (London) has attracted people's attention and emphasized that "open inquiry is at the heart of the scientific enterprise. Publication of scientific theories—and of the experimental and observational data on which they are based-permits others to identify errors, to support, reject or refine theories and to reuse data for further understanding and knowledge. Science's powerful capacity for self-correction comes from this openness to scrutiny and challenge" [11] (p. 7).

Data, information, and knowledge and their translations are fundamental to science and its relations with society as much as for open scientific research [3] (p. 14). However, this notion of openness is based on the premise that data, information, and knowledge are accessible, intelligible, and usable openly to scientists and members of society [3]. With this overarching ideal, international regimes such as UNESCO and other agencies govern and sustain open science for the benefit of society with minimal relevant restrictions and regulations. One important insight that comes out of the paradigm of open and autonomous science is the factor of scientific progress and systematic knowledge advancement over the years. For instance, Alexander Fleming, who is credited with the discovery of Penicillin in 1928, did not willingly patent it and made its research results and science open for peer community and society. Similarly, there was a good deal of open science, information, and facts for discoveries such as the transistor, DNA, Double Helix, light bulb, among several others. Publishing of open science information in a peer-reviewed medium was freely available and used by the peer community leading to scientific progress. For instance, the Double Helix of Crick and Watson led to the future of molecular biology after their discovery.

Entering the third decade of the 21st century, this scientific social system and the social contract between science and society are undergoing major changes. It is threatened by various societal, market—economic, authoritarian—and global forces. In fact, the whole paradigm of open science and its social contract is challenged by various "enemies" or adversaries reminding us of the influential work by Karl Popper, The Open Society and its Enemies published in 1945 [12]. This classic was acclaimed as an important voice of democracy and free society. The era preceding this book witnessed the most devastating and horrible experiences the world has ever faced from the extremities of fascism and Nazism. In a different form and organization, open science today confronts new enemies and adversaries. There are numerous challenges to sustaining the ideals of the open science paradigm and particularly the science-society social contract which benefits society in varying ways. These challenges are coming, primarily, from (a) market-based privatized science, (b) 4.0 Industrial Revolution technologies, and (c) a new iron curtain obstructing the free flow of scientific data, information, and facts. The way restrictions on COVID-19 related scientific data and information led to conflicts between various governments and health agencies brings this issue into sharp focus. What impact will this have on our future sustainable science-society social contract [13]? These are some important issues that this article will discuss. 


\section{Challenges from Market-Oriented Privatized Science}

Historically speaking, open science and its social contract with society at large are fundamentally based on the ideal of public good in science. This means that the scientific community making scientific discoveries and disseminating systematic knowledge via journals and publications is in the public domain for the welfare of society at large. This form of communication plays an important part in the progress of science and the advancement of systematic knowledge. With privatization and markets assuming a greater role in shaping economies, the commodification of knowledge and profit-making has assumed considerable significance. Public interest and market interest are based on two different opposing logics: public disclosure vs. normative research based on market standards and guiding them toward research commercialization [10]. With the rise of globalization and the monopolization of knowledge by multinational corporations, the tension between these two logics has sharply increased. The challenges from market-based privatized science manifest in different forms and organizations that threaten open science.

\subsection{Threat to Basic Research and Public Good}

Even though basic research is currently pursued and conducted by private corporations, science councils, and universities, there is a dramatic transformation of profit motives and steering by market forces that set priorities away from the public good of science. The way in which basic research was relatively open and driven by a curiosity for the advancement of knowledge has taken a big hit and is curtailed in large publicly funded science organizations such as CNRS (Paris, France), CSIRO (Canberra, Australia), NRC (Ottawa, Canada), CSIR (New Delhi, India, and Pretoria, South Africa) and several other countries and councils [14]. For instance, a Global Young Academy report on Canada drew attention to the long-term shift toward applied research (see ref. [15]). A survey of 1303 Canadian researchers showed that basic science dropped from $24 \%$ in 2006 to $1.6 \%$ in 2015 . According to the American Association for Advanced of Science, the Trump administration's science budget proposal includes a $17 \%$ reduction in basic research funding (see ref. [16]). The US Information Technology and Innovation Foundation pointed out that federal basic research has been declining in 22 of 28 years. As a percentage of GDP, Federal Research has fallen from a high of $2.5 \%$ in 1964 to $0.61 \%$ in 2018 [17]. A recent book by David R. Johnson on the conflict between professional commercialization and academic science clearly illustrates how commercialism penetrates the structure of the American higher education system [18]. David believes that "the profit motive in science creates a situation where scientists place their own value and potential personal interests above the public interest." Such trends are quite evident in the OECD and other countries. Social safety nets, welfare, and health-related measures take care of poor people to a large extent in these industrially advanced countries. However, it has become a major problem across the developing world. Science as a public good is drastically curtailed in publicly funded agencies in the developing countries of Africa, Asia, and Latin America. In general, public-funded science in developing countries not only lags compared to those in developed countries but has over the years, declined in crucial sectors of public health, education, and food security as can be seen in the recent UNESCO Science Report: Towards 2030 [19]. The space for the public good of science is rapidly shrinking in both developed and developing countries. The priority given to the science of privatization has begun to have a profound and serious impact on some developing countries. The recent problem of COVID-19 has clearly demonstrated this in the case of the health sector in developing countries and as well as in emerging economies like India, Mexico, South Africa, and Brazil. The main reason for the shrinking of the public good of science (and hence blockades for open science) is secrecy in science or a trend towards intellectual property rights.

\subsection{Secrecy and Intellectual Property Rights (IPRs)}

In every country, the state or government invests large sums of taxpayer money in research and development $(R \& D)$ and scientific research under the legitimation of the public good of science. 
In addition to this funding, the private sources of funds for science have tremendously increased in every country over the last couple of decades. In the OECD, the USA, East Asian Dragons, and BRICS the private sources of total gross expenditure on research and development at a global level now constitute more than $78.13 \%$ (see refs. [20,21]). Given this privatized science, the drive towards secrecy in research and IPRs has come into sharp focus in TNCs and corporations. As noted above, even large science councils have over the years promoted IPRs in research. Hence, the most severe threat to open science comes from IPRs and secrecy in science. One is accepting that IPRs are a social reality and not at all rejecting them completely. What is being advocated here is creating a level playing field through science and innovation policy measures to sustain the space for the public good of science. In February 2004, 60 well-known academics, including 20 Nobel Prize winners, accused the US government of appointing experts with a lack of professional competence and conflicts of interest to various scientific committees. They asked the US Environmental Protection Agency to stop suppressing data related to public health and respect the disclosure of scientific information [22]. The Royal Society of London (Royal Society of London) pointed out in its report Science as Open Enterprise (2012) that "the economic reasons for universities to more strictly control intellectual property rights are doubtful. In the seven years from 2003/2004 to 2009/2010, the income of British universities has increased by 35\%" [3] (p. 47). Corporates and TNCs have penetrated the elite universities in the USA with funding frontline scientific research and steering it towards a profit-oriented commercial end. In collaboration with Novartis in 1998, the University of California entered into an agreement for 25 billion USD. Novartis will have access to critical research information and will steer $33 \%$ of discoveries for years. Ignacio Chapela and David Quist, who mounted opposition to the collaboration and opposed this deal were persecuted. They had to leave their jobs for voicing criticism [22] (p.14.). This is not an isolated example. This practice of corporate industrial investments into academic universities in the USA, Europe, and other parts of East Asia has gained tremendous significance [23]. Traditional knowledge of yoga from India which has been freely disseminated the world over for centuries has now come under heavy attack from international corporates. The US Patent and Trademark Office is reported to have issued clearance for several yoga-related intellectual properties. Even the yoga mat has been patented [10].

\subsection{Regulation of Science by Commercial Corporates}

For a long time, scientific research and knowledge certification were based on peer evaluation and regulated by the scientific community. Publications in peer-reviewed journals played an important role in regulating scientific knowledge before reaching the public domain. Scientists traditionally selected their research problems based on scientific merits and research questions generated within the social institution of science. Much of the research priorities were determined by factors and entities within the scientific community. All over the world, several leading countries and their governments allocated large sums of money to scientific research but did not, in any big way, interfere with the day to day functioning of the research system. With the beginning of globalization, particularly since the 1990s, the relative freedom enjoyed by science institutions changed and science governance came to be encroached by several market stakeholders. The market-related priorities both in public science labs and universities transformed the social control of science operating in the institution of science. This practice has taken several forms and currently, even scientific communication is subjected to machine learning and automation. As Mirowski [24] drew our attention, the US Patent Office issued US Patent 9430468 entitled "Online Peer Review and Methods" in 2016. Elsevier is the owner of the patent. The core feature of these patents is the process of organizing and implementing peer review on computer programs. Another platform-based automatic peer review reported in recent years is a natural language generator that can generate credible research reports (see ref. [25]). New technology, which is being utilized in detecting fraud, copying, plagiarism, and scanning research theses for spelling and other constructive purposes is very welcome. However, AI and machine learning techniques being used for what Mirowski [24] calls "platform capitalism" in the name of open 
science, moving towards commercialism, monopoly, and profit-making are destroying the conventional science and society relationship. Advances in health-related biomedical research are no longer vetted by a peer-based system by the scientific community, but by different corporate partners in scientific projects. For instance, during April-June 2020, one can see how scientific developments and research processes progressing in COVID-19 related vaccines are being reported in mass media and leading newspapers much before they find their way into peer-reviewed science journals.

One can witness several disruptive practices in the priorities of scientific research. The Social Health-Related Science project of the British Economic and Social Research Council (ESRC) concluded that $90 \%$ of the world's health research is spent on issues that affect only $10 \%$ of the world's population (ESRC [26]). In the 1990s, some developing countries such as India opposed Monsanto's "terminator gene". Such practices are quite widespread and rampant, clearly showing how scientific research guides the maximization of profits. There are several examples in the case of leading US universities on how big enterprises and business firms have penetrated the academic research system. For example, the Whitehead Institute of Biological Sciences has invested a lot of money in the Massachusetts Institute of Technology since the 1990s, and it is located on the MIT campus. This type of transformation in the institution of science is quite visible in several leading Ivy League universities in the USA and leading universities in Europe such as Cambridge and Oxford. The radical change in the academic culture and institutions of higher learning is rapidly transforming the traditional social contract between science and society [27].

The commercialization of research has become an inseparable part of university academic science, academic policies, teaching, and research. Before the 1990s, there were no similar concepts to the "entrepreneurial university", but as Etzkowitz [28] predicted, this concept spread like wildfire. For example, the National University of Singapore "aspires to become an important community for academics, researchers, employees, students and alumni, who are committed to a better world in a spirit of innovation and progress" (see ref. [29]). All major universities institutionalize the concept of entrepreneurial university entities in some form. The science park and innovation park have now become part of traditional universities. TNCs and corporates have established various commercial collaborative programs and joint ventures with universities, not for advancing knowledge but for profiting from university-based academic science. The St. John's Innovation Center and Incubator at Cambridge University, the Tuspark at Beijing's Tsinghua University, and the Technology Park at the Indian Institute of Technology in Madras are some examples. Earlier, multinational companies and universities used to keep a certain distance. One could easily distinguish organizational cultures and goals distinctly. However, the last couple of decades witnessed tremendous close collaborations and partnerships between academia and industry. The Novartis case noted above at the University of California is not an isolated case. One can recall the famous development at the beginning of the biotechnology revolution. The scientific research of Herbert W. Boyer and Stanley Cohen led to recombinant DNA technology and ultimately led to the establishment of the biotechnology company Genentech (1976), which was a "sensational" company on the American Stock Exchange. Imperial Innovations is a UK technology commercialization and investment company, which formed in 1986 as a department of Imperial College London. Since 2006, shares of the company have been traded on the London Stock Exchange (see ref. [30]). The IP Group in the UK, an intellectual property commercialization company, has invested large sums of money at Princeton University, John Hopkins, University of Pennsylvania, Yale, and Washington University. In 2001, the IP Group invested 30 million USD to build a chemistry building at the University of Oxford. Their main purpose is to acquire shares in start-ups established around the intellectual property of the Department of Chemistry (see ref. [31]). Allied Minds, another Boston based start-up investment firm has links with 34 US universities. Similar is the case with Tsinghua University in China. Academic institutions, which were quite removed from the stock exchange in the past, are now entering into the commercial and trading domain in some form. This is indeed a huge change in the past 15 years. 


\section{Industrial Revolution 4.0 and Its Challenges for Sustainability}

In the last decade, if there is one important science, technology, and innovation policy discourse that has caught the imagination of world leaders and governments alike, it is the perspective and strategy of the Fourth Industrial Revolution or IR 4.0 technologies. After the First, Second, and Third Industrial Revolutions, respectively, we are now entering into yet another paradigm of scientific and technological transformation characterized as the Fourth Industrial Revolution. It is the fusion of AI, Robotics, IoT (Internet of Things), and physical and biological sciences. Sundar Pichai, the Chief of Google and Alphabet at Davos observed that "the combination of artificial intelligence and quantum computing will help us solve some of the biggest problems we see ... When I look to the future, I will say: 'How do we promote improvements?' - quantum will be one of the tools in our arsenal" [32]. In a similar vein, IBM chief Gini Rometty in 2019 at Davos observed that in the coming decades "AI will completely transform almost every business on the planet. The shift to the era of cognitive enterprise will be a multi-step journey but it is one that has the potential to create massive value for the business and drive the next phase of competitive advantage" (see ref. [33]). Similar foresight was expressed by most leading corporations and influential leaders. Despite the euphoria over the Fourth Industrial Revolution and its optimistic view as a harbinger of a new era, clear signals of technological threat were expressed. Professor Klaus Schwab, the founder and executive chairman of the World Economic Forum, clearly stated his vision of industry 4.0 for our society in the book, The Fourth Industrial Revolution.

The previous industrial revolution liberated humans from the power of animals, made mass production possible, and brought digital capabilities to billions of people. However, this fourth industrial revolution is fundamentally different from this. It is characterized by a series of new technologies that merge the physical world, digital world and biological world, affect all disciplines, economies and industries, and even challenge the meaning of mankind. The resulting changes and chaos means that we are living in an era full of hope and great danger ... Organizations may not be able to adapt; the government may not be able to use and supervise new technologies to obtain its benefits; the transfer of power will create new major security issues; Inequality may increase; societies fragment [34].

Despite Schwab's warnings of "great peril" for society and that "inequality may grow; and societies fragment", techno-scientific innovations of industry 4.0 were accepted as the most important agenda of science, technology, and innovation policies by each and every country on the globe. More than anything else, techno-science frontiers associated with industry 4.0 were viewed as a "technological fix" for innumerable problems. Techno-science signifies how basic science has so much become an integral part of technology development. One may see the fusion in big data science, big data analytics, AI, robotics, IoT, among other advancements in the present day knowledge frontiers. In other words, there is a sense of technological determinism that dramatically transforms the way we live, move, and help to create new entities in this physical environment. We will have to learn to adapt to this technological change as it also has solutions to various problems. There is indeed a strong belief in the perspective that technology is uncontrollable and unpredictable by humans, causing people to feel helpless in front of the explosion of this new era 4.0 techno-scientific world. Associated with this is the recognition that technology is autonomous (and in many ways neutral) in its trajectory and that we in our society need to adapt to these changing techno-scientific world views (see refs. [35,36]). The technological deterministic views associated with the scientific and technological advances of industry 4.0 pose one of the biggest challenges to the science-society social relationship. As Yuval Noah Harari in his recent book Homo Deus: A Brief History of Tomorrow (2016) draws our attention [37], the advances in the techno-sciences of 4.0 are likely to create a ripple effect on society and economy against inclusive innovation. A "new cognitive violence" is likely to be unleashed on our society which is already being felt in developed as well as developing societies in livelihoods and the nature of work. In many ways, there are innumerable examples to demonstrate how the traditional and existing science-society contract based on inclusive science and technology and the public good of science is being disrupted 
in favor of the "one-dimensional" view of creating wealth and power in national economies through advances in AI, robotics, quantum, and several techno-sciences associated with industry 4.0.

Mega-corporations such as Google, Facebook, IBM, Microsoft, Amazon, Alibaba, and Didi among several others that dominate in the 4.0 techno-sciences have already unleashed profit-oriented consumerism, labor-saving, and dehumanizing surveillance devices (see ref. [38]). ImageNet is the world's largest image recognition database. As we all know, it is a visual object recognition tool designed for large companies such as Amazon and Facebook. ImageNet was established by computer scientists at Stanford University and Princeton University in the United States and is considered the beginning of the deep learning revolution (see ref. [39]). One can see the way technological determinism plays out in its varying forms. For instance, the whole science and innovation policy focus is being laid on AI mimesis that is the ability of machines to perform tasks that normally require human intelligence. This is likely to not only render the loss of human work and livelihood but will also dehumanize or alienate society and people. Face recognition technologies have already led to the threatening of privacy and human rights (see ref. [40]). The most devastating impact of science and technologies behind the Fourth Industrial Revolution is expressed by the guru of Davos and one of the pioneers of this phase of industrial trajectory, Klaus Schwab.

In the final analysis, everything comes down to people and values. We need to shape a future that works for all of us by putting people first and empowering them. The Fourth Industrial Revolution, in its most pessimistic and inhumane form, may indeed be possible to "robotize" human beings, thereby depriving us of our hearts (Schwab [34]).

The International Labor Organization estimates that $70 \%$ of Vietnam's jobs are likely to be replaced by artificial intelligence machines. The report also points out a series of jobs that are vulnerable to current or future technological automation. The International Labor Organization cited in a research report that $47 \%$ of American jobs, $36 \%$ of British jobs, and other figures ranging from $55 \%$ in Uzbekistan to $86 \%$ in Ethiopia, are at risk. Another major development agency (UNDP) report on Asia has drawn attention to an unprecedented risk of automation in East Asian "Tigers" (Hong Kong, Singapore, South Korea, and Taiwan) and China, in addition to countries such as Malaysia, Vietnam, and Thailand. It is established in the field of automation in the manufacturing industry, including electronic technology, automobiles, and clothing that Robotic Process Automation (RPA) threatens the service industry. These industries have promoted GDP and unemployment in India and the Philippines [41] (pp. 22-24). Besides work and job losses, there is the whole issue of the ethics of AI-related technologies and their operation in society. Even before regulatory agencies and governments realize the social implications, a number of ethics-related problems have come into sharp focus. Issues of ethical lapses in the use of AI-related technologies have been raised from different quarters related to the accuracy of information and data being used as well as privacy, transparency, accountability for unfair trading, among other related issues. Industry 4.0 scientific and technological advances have generated much hype, undermining the inclusive science and innovation underlying the science and society social contract. Although big companies promise to create a world of efficiency, productivity, and a new economic miracle, these tools promote and amplify concerns about technology-driven unemployment and overall social inequality. Globalization has already created a gulf between the rich and poor within and across countries (Piketty [42]). This will be further accentuated with the coming of a new industrial revolution.

\section{Democratic Deficit and New Iron Curtain for Free Flow of Information}

Robert Merton's [4,5] normative structure of science and his insights calling for a democratic social order for the advancement of systematic knowledge is one of the foundational features of the science and society social contract and that of open science. "In a modern totalitarian society, anti-rationalism and centralized institutional control have restricted the scope of scientific activities" [5] (p. 78). As Everett Mendelsohn [43] (pp. 269-289) points out, Merton's focus on the critical factor of 
open science was in fact rooted in Nazism and the elimination of some elite scientists in Germany as much as it was due to the extremities of Soviet-style communism. This perspective of science and democracy came into sharp focus in the last several decades whenever science and its free flow of information and facts came under severe threat [11]. The understanding of science and democracy also stems from the views and concepts of "civic science" or the public's understanding of science. The Royal Society promotes the public understanding of science, which is one of its main activities (see ref. [44]).

As Alan Irwin [45] observes, citizen science is "the concept of developing scientific citizenship, which foreshadows the necessity of opening up science and science policy processes to the public." Even though citizens could systematically investigate independently, in the end, research results will have to be peer-reviewed by the science community. Even in disputes and scientific controversies that land up in courts, there are technical evaluation committees set up to adjudicate who represents the science community. As Brancom and Rosenberg [11] point out, science and democracy share the same values. The foundation of a democratic society is public debate, free flow of information, mutual respect, and the key role of investigation and evidence. As Milovsky [24] (p. 176) pointed out, "since 1980, the situation has undergone another major change, from a science mainly funded by the military and the state-sponsored science to a science primarily subordinate to market considerations, organized by corporate patrons and academic contractors" [24] (pp. 171-203). The way in which the science and society social contract and the social institution of science have suffered is evident from the recent developments in the USA over COVID-19 dealings. As the recent Brookings institution reports and draws attention (see ref. [46]), destroying trust in science has left America vulnerable to the COVID-19 pandemic. It points out, "science has become another Trump target. Whether it is suspicion of climate change, support for cuts in basic research funding, or hostility to general universities, they have trained their rhetorical weapons on the scientific community with devastating impact." As early as 30 November 2016, more than 2300 scientists (including 22 Nobel Prize winners) wrote to the Trump administration and Congress to take actions in four areas to create: (a) a strong and open scientific culture, (b) ensure public safeguards of clean air grounded in science, (c) adhere to high standards of scientific integrity and independence, and (d) sufficient scientific resources (see ref. [47]). It is not accidental that the OECD's policy response to COVID-19 proposed three messages on "why open science is important to fight against COVID-19". These are:

- In a global emergency such as the Coronavirus (COVID-19) pandemic, open science policies can remove barriers to the free flow of research data and ideas, thereby accelerating the pace of research that is critical to combating the disease.

- Although the global sharing and collaboration of research data has reached an unprecedented level, challenges remain. Trust in at least some data is relatively low, and outstanding issues include the lack of specific standards, coordination and interoperability, as well as data quality and interpretation.

- In order to strengthen the contribution of open science to COVID-19 response measures, decision makers need to ensure appropriate data management models, interoperable standards, sustainable data sharing agreements involving the public sector, private sector and civil society, incentives, sustainable infrastructure, human and institutional capabilities and mechanisms to obtain data across borders [48].

As is widely known and publicized in the scientific and general media, there is a critical discourse emerging on the way in which scientific information and research results on COVID-19 are being regulated in China. There is international concern as reported in the leading British science journal, Nature (15 April 2020) that "the Chinese government has started asserting strict control over COVID-19 research findings. Over the past two months, it appears to have quietly introduced policies that require scientists to get approval to publish... at least two Chinese universities have posted online stating that research on the source of the virus needs to be approved by the university's academic committee 
and the Ministry of Science and Technology, (MOST) or Ministry of Education before being submitted for publication." A coalition of over 60 countries has asked for an independent inquiry into how the virus emerged and spread in Wuhan. In fact, Chinese President Xi Jinping, in response to the global discourse on COVID-19, "supports a comprehensive review of the global response to the COVID-19 pandemic led by the World Health Organization (WHO) after the virus that causes the disease is brought under control" (see ref. [49]). Beyond the political standpoints and conflicts over COVID-19 and its origins, open science communication has become a major victim. It is not surprising that the global network of science's collaboration on sharing research results on this pandemic and containing its spread through the World Health Organization has come into sharp focus.

In January 2020, 117 organizations, including journals, funding agencies, and the Centers for Disease Control, signed a statement promising to provide immediate and open access to peer-reviewed publications at least during the outbreak of the pandemic. The print server provides the research results and immediately shares them with the World Health Organization. This was followed by the public health emergency COVID-19 initiative launched by 12 countries in March, calling for open access to publications and machine-readable data related to COVID-19. Subsequently, an international alliance of scientists, lawyers, and technology companies initiated the COVID pledge in April 2020 to provide all intellectual property (IP) under its control (see ref. [49]). International collaboration, networking of science communication based on empirical research on COVID-19 health issues, and above all, free flow of information have become critical factors in finding a solution to this global problem. Secrecy and suppressing data and information on the growing pandemic problem have become a major contention amongst countries. International agencies are urgently calling the attention of countries and governments towards open science. A major policy thrust for open science from OECD has now come out with certain recommendations for actions during COVID-19 crisis [48].

- Develop a data governance model to allow open research data by default while protecting personal privacy.

- Provide a regulatory framework to enable interoperability within large electronic health record providers, patient intermediary exchanges, and peer-to-peer direct exchange networks.

- Public actors, private actors, and civil society work together to formulate and/or clarify a governance framework in order to credibly reuse privately held research data for public interest.

- Clarify incentives and rewards for researchers, and require immediate disclosure of data, software, and protocols for release. Institutions and national policies should address the issues of recognition and cultural/structural barriers between data providers and transform the system into a culture based on sharing.

- Securing adequate infrastructure (including data and software repositories, computational infrastructure, and digital collaboration platforms) to allow for recurrent occurrences of emergency situations.

- Ensure sufficient infrastructure (including data and software repositories, computing infrastructure, and digital collaboration platforms) to allow repeated emergencies.

- Ensure that there is sufficient human capital and institutional capacity to manage, create, curate and reuse research data.

- Enabling access to sensitive research data across borders on a more restricted basis in secure environments. This primarily concerns clinical data which may not be allowed to leave the original repository, but could potentially be accessed by mobile algorithms which could use the data to answer specific research questions [48].

These international developments and voices raised in the last few years are due to an increasing threat to open science and communication from big transnational corporations and of late from some authoritarian regimes. A major threat to open science has come from what has come to be known as platform capitalism which refers to the activities of companies such as Google, Facebook, Apple, Microsoft, Uber, and Airbnb operating as platforms. They are monopolizing data of all sorts to use in 
their commercial and corporate affairs and trading. British Newspaper, The Guardian, observes "data is the new oil. Just as John D Rockefeller's Standard Oil swept the spoils of the-initial competitive-oil rush, the future of the internet will be shaped by a handful few tech titans, including Google, Apple, Facebook, Amazon and their Chinese equivalents Tencent, Alibaba, and Baidu" (see ref. [50]). As Yuval Noah Harari pointed out, "those who control the data control the future not just of humanity, but the future of life itself. The rise of machine learning and deep learning, smart artificial intelligence software can mine huge sets of data and find meaningful patterns that would go unnoticed to the biologically limited minds and human beings" (see ref. [51]). Besides, there are leading big data and data science firms such as IBM Watson which are in the business of biomedical data. These firms systematically collect data and information on bioinformatics, clinical informatics, imaging informatics, and public health informatics. The trend of big data and data science poses a big challenge when personal and publicly funded health data is appropriated under public-private partnership arrangements. In most cases, the whole ethical, personal, and privacy issues are either glossed over or regulatory measures are insufficient to protect the fundamental rights of persons. This data, which becomes an important resource, is used by companies to create value without providing people with reasonable compensation. Regulating and sustaining a healthy science and society relationship is a big challenge that is being debated by the science community and international agencies such as UNESCO.

\section{Concluding Remarks}

Science as a social institution, that has been governed and controlled by the science community for the last three hundred years, has come under severe threat in the 21st century. Open science as opposed to intellectual property rights, science for public good as opposed to market good, peer review, and the prominence attached to open publications, that characterize the science and society social contract, are rapidly disintegrating. The social institution of science has now come to confront several enemies that stand to threaten its character of knowledge as a public good and the ethos underlying the science-society social contract. Our past experience shows that open knowledge has its own advantages because it helps solve many important practical problems, and it also helps raise the threshold and paradigm of new knowledge [10]. This change is no less than the "Cultural Revolution" in science. As demonstrated in this essay, the main threat to open science is unleashed by rapidly growing profit-oriented market-based privatized science, unethical and unregulated techno-sciences of the Fourth Industrial Revolution, and the new "iron curtain" of the free flow of scientific data and information. This last feature assumes enormous significance in the current context of the COVID-19 pandemic that has spread like wildfire. The very success in finding a solution to this problem depends on institutional structures and nation-states that facilitate the free flow of scientific information and data.

Social change and social transformations are part of our evolutionary life-world in society. Science, technology, and their progress are very much part of this transformation. In view of this understanding, some institutional safeguards for managing intellectual property must be established to maintain the free flow of scientific information and data, so as not to hinder the further development of science. Privatizing basic knowledge is a danger to scientific and technological progress [52] (p. 356). The dangers of some crucial technologies of nuclear, telecom, and biological research are currently regulated by various regimes such as Nuclear Suppliers Group, International Telecommunications Union, and RNA and DNA regulatory committees in various countries. Hence, there is a good reason to adopt appropriate regulatory regimes in the case of the most disruptive industry 4.0 technologies such as robotics, AI, and machine learning, among others, which threaten livelihoods and are likely to infuse alienation in society. We have witnessed earlier industrial revolutions but this current one is radically different in pace, speed, and impact. It entails several damaging features for a sustainable society if not regulated or socially controlled. Some cases, which entail ethical and dangerous signals, call for international regimes of regulation. In some others, national governments will have to deal case by case as relevant and appropriate to their respective socio-economic milieus. 
From the perspective of science and technology policies, as Pandey et.al. [53] and Bijker [54] argue, we need to bring in various policy measures on responsible research and innovation (RRI) to accommodate uncertainty and augmented dangers. As Pandey et al. [53] clarified, from the key insights of previously controversial technologies, as well as insights into the uncertainties and lack of knowledge related to the future, RRI stipulates that research and innovation should go through a process of anticipation and reflection [53] (p. 217). In some critical technologies which threaten life (COVID-19 for instance) and endanger sustenance (for instance green and low carbon technologies), there is a need for invoking institutional measures of what has come to be known as "Scientific Commons". This is particularly crucial for poor developing countries. In some other cases of new technologies and in the biomedical domain, costly therapies have become highly restrictive and prohibitive due to strong IPRs, there is a need to extend the scope and umbrella of access through some policy measures such as "Compulsory Licensing" arrangements. In the field of climate change, there is already a concept of common but differentiated responsibilities. This concept is based on the historical responsibilities of countries and their different capabilities in responding to climate change. Thus, what is being argued is for appropriate science and innovation policy measures to create a level playing field between open science and market-oriented privatized science. As argued elsewhere [10], globalization has become a reality in our society, economy, and daily life. How can we save scientific institutions from being completely replaced by globalized economic and market-oriented forces? As Amartya Sen has correctly observed from an economic perspective, we need to develop mechanisms to maintain a level playing field between public good and market good. We need to develop institutional mechanisms and policy tools to "make globalization work for all, not for the few." Professor Amartya Sen discussed this with Joseph Stiglitz and Dr. Manmohan Singh at the FICCI seminar held in New Delhi around 2003.

In the post-war era, developing countries benefitted immensely from the liberal, democratic global science institutions which were governed by the ethos of open science and the science-society social contract. Industrially advanced countries invested large sums of money in academic science and developed world-class universities. In the post-COVID-19 phase, economically battered economies of industrially advanced countries are more likely to create difficult entry barriers and access to these prestigious institutions. This global window of opportunity for research access which operates with the unfettered ethos of open science will be severely restricted. This is due to the increasing commodification of knowledge and market-driven profit-oriented global R\&D in industry 4.0 technologies and biomedical techno-sciences particularly. The technological imperialism unleashed by industry 4.0 technologies of $\mathrm{AI}$ and automation has already rendered tens of thousands of workers jobless in some South Asian and East Asian economies (see ref. [55]). With low and stagnant investments in higher education and science and technology research in the last decade, the technological dependency of poor developing countries on advanced and emerging economies will increase rapidly. Some clear signals are already evident in the case of some African countries such as Angola, Sudan, Congo, Zambia, among others, which continue to experience acute problems of food and health security. Some developing countries in Latin America, Asia, Africa invest a meager sum of $0.1 \%$ to $0.5 \%$ of their GDP on science and technology (S\&T) research, falling short of a magic figure of at least $1 \%$ of GDP recommended by UNESCO [56]. They must evolve new endogenous science, technology, and innovation policy strategies to not only sustain the onslaught of industry 4.0 technologies but safeguard livelihoods through basic research in agriculture and health sciences. Basic research and public spending on S\&T are not a luxury but an essential factor of development and sustainable strategy in the future of the developing world. One is aware that developing countries are not homogenous. One is referring to poor developing countries according to the UN index, excluding those emerging economies such as BRICS. China and to a lesser extent India are good examples of such economies averting the syndrome of dependence in the crucial sectors of food, health, and other sectors through investments in science and technology. 
Author Contributions: This whole paper was structured and written by V.V.K. who carried out research in Asia-Pacific countries in the last four years. Much of the field research was undertaken during several trips to various Asian countries, Australia, and New Zealand. The author has read and agreed to the published version of the manuscript.

Funding: This paper was presented as a keynote speech at SOItmC 2020, and the publishing fee was supported by SOItmC.

Conflicts of Interest: Some material and portions of the paper were drawn from the author's own research and earlier research papers and books. These are fully acknowledged and there is no conflict of interest in this regard.

\section{References}

1. Bernal, J.D. Science in History; Faber \& Faber: London, UK, 1954.

2. Mac-Leod, R. Changing perspectives in the social history of science. In Science, Technology and Society-A Cross Disciplinary Perspective; Rosing, I.S., de Solla Price, D., Eds.; Sage: London, UK, 1977.

3. The Royal Society. Open Science and Its Enterprise; The Royal Society: London, UK, 2012.

4. Merton, R.K. Science, Technology and Society in Seventeenth Century England. Osiris 1938, 4, 360-362. [CrossRef]

5. Merton, R.K. The institutional imperatives in science. In Sociology. Ofscience-Sociology Readings; Barnes, B., Ed.; Penguin Books: Victoria, Australia, 1972.

6. Haldane Principle (Wikipedia). Available online: https://en.wikipedia.org/wiki/Haldane_principle\#: \{\{\}: text=In\%20British\%20research\%20policy\%2C\%20the,by\%20researchers\%20rather\%20than\%20politicians (accessed on 24 July 2020).

7. Bush, V. Science: The Endless Frontier: A Report to the President; United States Printing Office: Washington, WA, USA, 1945.

8. Polanyi, M. The republic of science. Minerva 1962, 1, 54-72. [CrossRef]

9. Mansfield, E. Academic Research and Industrial Innovation. Res. Policy 1991, 20, 1-12. [CrossRef]

10. Krishna, V.V. Changing Social Relations between Science and Society: Contemporary Challenges. Sci. Technol. Soc. 2014, 19, 133-159. [CrossRef]

11. Branscomb, L.M.; Andrew, A.R. Science and Deomocracy; The Scientist: New York, NY, USA, 2012. Available online: https://www.the-scientist.com/critic-at-large/science-and-democracy-40425 (accessed on 24 July 2020).

12. Popper, K. The Open Society and Its Enemies; Princeton University Press: Princeton, NJ, USA; Oxford, UK, 1945.

13. Sustainability Science Program. Available online: http://www.cid.harvard.edu./sustsci/overview.html (accessed on 24 July 2020).

14. Krishna, V.V. India's CSIR, the CNRS in France and the CSIRO. Innov. Manag. Pract. 2007, 9, $192-202$.

15. Restoring Canada's Competitiveness in Fundamental Research: The View from the Bench. Global Young Academy, Germany. 2017. Available online: https:/globalyoungacademy.net/wp-content/uploads/2017/06/ GYA-2017-FundResearchReport-LoRes.pdf (accessed on 24 July 2020).

16. Johnson, D.R. With Federal Funding for Science on the Decline, What's the Role of a Profit Motive in Research? Available online: https://theconversation.com/with-federal-funding-for-science-on-the-declinewhats-the-role-of-a-profit-motive-in-research-93322 (accessed on 24 July 2020).

17. Collins, M. Declining Federal Research Is Hurting US Innovation. Available online: https://www.industryweek.com/the-economy/public-policy/article/21121160/declining-federal-researchundercuts-the-us-strategy-of-innovation (accessed on 24 July 2020).

18. Johnson, D.R. Fractured Profession Commercialism and Conflict in Academic Science. Available online: https://jhupbooks.press.jhu.edu/title/fractured-profession (accessed on 24 July 2020).

19. United Nations Educational, Scientific and Cultural Organization. Unesco Science Report: Towards 2030; Unesco: Paris, France, 2017.

20. Global Private and Public R\&D Funding. Available online: https://scienceogram.org/blog/2013/05/sciencetechnology-business-government-g20/ (accessed on 24 July 2020).

21. World Trends in R\&D Private Investment. Facts and Figures. Available online: https://ec.europa.eu/ commission/presscorner/detail/de/MEMO_14_2347 (accessed on 24 July 2020).

22. International Council for Science. Science and Society-Rights and Responsibilities; ICSU, UNESCO: Paris, France, 2005. 
23. Krishna, V.V. Universities in the National Innovation Systems: Experiences from the Asia-Pacific Nations; Taylor and Francis Group, Routledge: London, UK; New Delhi, India, 2018.

24. Mirowski, P. The Future(s) of Open Science. Soc. Stud. Sci. 2018, 48, 171-203. [CrossRef] [PubMed]

25. Computer-aided Peer Review: How Automation Might Influence Academic Publishing. Available online: https://www.enago.com/academy/computer-aided-peer-review-how-automation-might-influenceacademic-publishing/ (accessed on 24 July 2020).

26. Economic and Social Research Council. Science, Technology and Globalization; ESRC Science in Society Programme: London, UK, 2003.

27. Krishna, V.V. Universities in the National Innovation Systems: Emerging Innovation Landscapes in Asia-Pacific. J. Open Innov. Technol. Mark. Complex. 2019, 5, 43. [CrossRef]

28. Etzkowitz, H. MIT and the Rise of Entrepreneurial Science; Routledge: London, UK, 2002.

29. National University of Singapore. Available online: http://www.nus.edu.sg/about (accessed on 24 July 2020).

30. Imperial Innovations (Wikipedia). Available online: https://en.wikipedia.org/wiki/Imperial_Innovations (accessed on 24 July 2020).

31. Thayer, A.M. Investment Firms Nurture University Start-ups. Available online: https://cen.acs.org/articles/ 93/i40/Investment-Firms-Nurture-University-Start.html (accessed on 24 July 2020).

32. Pichai, S. This Is the Biggest Risk We Face with AI. Available online: https://www.weforum.org/agenda/2020/ 01/this-is-how-quantum-computing-will-change-our-lives-8a0d33657f/ (accessed on 24 July 2020).

33. IBM at Davos: Business Leadership in the Fourth Industrial Revolution. Available online: https://www.ibm. com/blogs/think/2019/01/ibm-davos-2019/ (accessed on 24 July 2020).

34. Klaus, S. The Fourth Industrial Revolution; World Economic Forum: Davos, Switzerland, 2017; Available online: https://www.weforum.org/about/the-fourth-industrial-revolution-by-klaus-schwab (accessed on 24 July 2020).

35. MacKenzie, D.; Judy, W. The Social Shaping of Technolog; Open University Press: Buckingham, UK, 1999.

36. Lin, E. The Social Shaping of Technology-Donald MacKenzie and Judy Wajcman. 2018. Available online: https://medium.com/@qienl/the-social-shaping-of-technology-donald-mackenzie-andjudy-wajcman-3d26ecf5c05c (accessed on 24 July 2020).

37. Harari, Y.N. Homo Deus: A Brief History of Tomorrow; Vintage Publishing: London, UK, 2017.

38. Kinzel, H. Industry 4.0-Where Does this Leave the Human Factor? J. Urban Cult. Res. 2017, 15, 70-83.

39. The Fourth Revolution. United Nations Educational, Scientific and Cultural Organizational. 2018. Available online: https://en.unesco.org/courier/2018-3/fourth-revolution (accessed on 24 July 2020).

40. Symopsium on Humane Artificial: The Challenges of Privacy and Social Cohesion. Available online: https://www.eastwestcenter.org/node/37961/2020-symposium (accessed on 24 July 2020).

41. UNDP. Development 4.0: Opportunities and Challenges for Accelerating Progress towards the Sustainable Development Goals in Asia and the Pacific; UNDP Asia Pacific: London, UK, 2018.

42. Piketty, T. Capital in the Twenty-First Century; Harvard University Press: Cambridge, MA, USA, 2014.

43. Everett, M.; Robert, K.M. The Celebration and Defense of Science. Sci. Context 1989, 3, 269-289.

44. The Royal Society. The Public Understanding of Science. 1985. Available online: https://royalsociety.org/ \{\}/ media/Royal_Society_Content/policy/publications/1985/10700.pdf (accessed on 24 July 2020).

45. Irwin, A. Citizen Science: A Study of People, Expertise and Sustainable Development; Routledge: London, UK, 1995.

46. Hetherington, M.; Ladd, J.M. Destroying Trust in the Media, Science, and Government has Left America Vulnerable to Disaster, Brookings. 2020. Available online: https://www.brookings.edu/blog/fixgov/2020/05/01/ destroying-trust-in-the-media-science-and-government-has-left-america-vulnerable-to-disaster/ (accessed on 24 July 2020).

47. Eilperin, J.; Mooney, C. Over 2000 Scientists Urge Trump to Respect Scientific Integrity and Independence. 2016. Available online: https:/www.washingtonpost.com/news/energy-environment/wp/2016/11/30/22-nobelprize-winners-urge-trump-to-respect-scientific-integrity-and-independence/ (accessed on 24 July 2020).

48. Organizations for Economic Co-Operation and Development. Why Open Science Is Critical to Combatting COVID-19? Available online: http://www.oecd.org/coronavirus/policy-responses/why-open-science-iscritical-to-combatting-covid-19-cd6ab2f9/ (accessed on 24 July 2020).

49. The Washington Post. Available online: https://www.washingtonpost.com/ (accessed on 24 July 2020). 
50. Cable, V. The Tech Titans Must Have Their Monopoly Broken-And This Is How We Do It. The Guardian. 2018. Available online: https://www.theguardian.com/commentisfree/2018/apr/20/tech-monopoly-applefacebook-data-extreme-content (accessed on 24 July 2020).

51. Dickson, B. AI, Big Data and the Future of Humanity. 2018. Available online: https://bdtechtalks.com/2018/ 01/31/yuval-harari-wef-ai-big-data-digital-dictatorship/ (accessed on 24 July 2020).

52. Nelson, R.R. The market economy, and the scientific commons. Res. Policy 2004, 33, 455-471. [CrossRef]

53. Pandey, P. Responsible Research and Innovation in the Global South: Agriculture, Renewable Energy and the Pursuit of Symmetry. Sci. Technol. Soc. 2020, 25, 215-222. [CrossRef]

54. Bijker, W.E. Constructing worlds: Reflections on science, technology and democracy (and a plea for bold modesty). Engag. Sci. Technol. Soc. 2017, 3, 315-331. [CrossRef]

55. International Labour Organization. Preparing for the Future of Work: National Policy Responses in ASEAN +6 ; ILO: Bangkok, Thailand, 2019.

56. United Nations Educational, Scientific and Cultural Organization. Toward a New Contract between Science and Society. Present at Executive Summary of the Report of the North American Meeting Held in Advance of the World Conference on Science, Kananaskis Village, AB, Canada, 1-3 November 1998.

(C) 2020 by the author. Licensee MDPI, Basel, Switzerland. This article is an open access article distributed under the terms and conditions of the Creative Commons Attribution (CC BY) license (http://creativecommons.org/licenses/by/4.0/). 